UDC 332.13

Одержано 15.09.2017p.

\title{
Hvizdová E.
}

\section{REGIONAL DEVELOPMENT THROUGH CRAFTS TOWARDS THE CREATIVE INDUSTRIES}

\begin{abstract}
Nowadays more and more there can be seen the impact of globalization on culture and the economy. Some of the negative traits are reflected in the backwardness of certain regions in Slovakia. The paper shows the options to solve unemployment by promoting traditional handicrafts and creative activity of residents, reflecting the traditions of the region. Creative potential of human capital can be utilized via upgrading of traditional folk crafts towards the creation of new advanced products with traditional elements. Expert interviews with professionals provide guidance to address the issue and also the existing situation.
\end{abstract}

Keywords: region, creative industries, craft. tourism.

Introduction. American professor expert on the issues of creative economy in collaboration with a group of his colleagues dealt with the measurement of creativity and creative abilities of the individual regions. Research has shown that creative people prefer places that are different and open to new ideas, where people are tolerant, and creative capital of the region is concentrated in these places. They applied creative index $3 \mathrm{~T}$ and via this model the regional economic growth is explained. 3T really means: talent, tolerance and technology [3]. Economic growth is directly dependent on talented people. New ideas, new non-traditional solutions, the new ability to take these solutions as well as new insights form a favourable environment for creative and innovative thinking. Innovation is a driving force of the knowledge economy. The author [4], points out that the most serious barrier to innovation in the market is that companies are not involved in the analysis of consumer demand, causing ignorance of their demands. The Creative Economy Report (2010) states that creativity is encountered in almost all areas in which one operates. Creativity can multiply the production, not only the level of technology and knowledge capital, and thus it becomes a major source of economic growth and quality of life in regions.

Cultural and creative industries driven by digital technologies create a new economy, i.e. creative economy. In the European Union creative industries employ more than 5.8 million people, representing about $3.1 \%$ of employed people in the European Union. An annual increase in employment is $12.3 \%$.

Literature review. Cultural environment in the region needs to create sufficient facilities for the development of young and new talented persons, as well as citizens and other users of cultural and

(C) Hvizdová Eva, Ing., Ph.D, MBA, College of International Business ISM Slovakia in Prešov, Duchnovičovo námestie 1, 08001 Prešov, e-mail: hvizdova@ismpo.sk technological products. This background has to be tolerated and accepted. The main prerequisite for growth is maturity and richness of the consumer, education of the workforce and its ability to create new value. In this context, the craft in general terms may be defined as small-scale production of specific products with a high proportion of manual labour for profit, self-employment, which requires a certain level of education. Folk craft and folk-art activities belong to small-scale production, the performance of the craft does not have to be tied to education (embroidery, crochet, lace making, weaving) rather binds to sharing experience in the family, consultations with specialists or even for personal self-didactic study. It may not and often is not a fullemployment activity, but additional form of earnings. As mentioned by Ambrozy, craftsmanship may be related to biodiversity, where just a significant element to distinguish it may be a "lace and embroidery well specific for the micro-region, sometimes even for its part" [1]. Not only Slovak folk crafts, but crafts in the world accounted for daily, manual work of people in past centuries. Individual crafts as a name for initially commercial creation of products (but today mostly only artistic ones) of those who managed it, brought in the daily life of our ancestors the products that were meaningful and useful. It goes without saying that today's life marked by the industrial revolution and showing the rapid development of many exciting and fast technologies pushes the old crafts into oblivion. Many of them have already been held only because the oldest generations. The traditional Slovak crafts include, for example: woodworking chiselling the wood, cooperage, splitting wood, turner's trade, and carving; processing clay pottery; glass processing - glasswork, painting on glass; metal processing - tinkering, jewelry design, production of little bells and cast bells, blacksmith; leather processing - tanners, saddlers, furriers; processing of horn; processing of natural tissue; 
making Easter eggs; making gingerbread; production of fabric - weaving, wool processing; production of embroidery - needlework; manufacture of lace - lace making; manufacture of blueprint - dyeing and blue-dyeing [6]. The Slovak folk art was overlapped and remodeled by art traditions of the territorial nearby nations, as well as by elements of the Carpathian-Balkan tradition associated with the pastoral element in the folk culture of Slovakia [2]. We now know that the areas operated by creative people are considered key, highly profitable and due to them such regions, nations and countries can be creative and best financed. Wiesand and Sondermann in Kloudová [5] speak in their studies about underestimation of the cultural sector, which has an impact on employment growth. In all activities of the creative sector there participates so-called secondary structure, encompassing free crafts and art. In this sector there are mainly arts and crafts focused on home furnishings and tourism (individual producers, entrepreneurs, family businesses, small businesses), traditional and folk crafts (individual producers without trade, entrepreneurs, family businesses up to nine employees, non-profit organizations), arts and crafts activities aimed at restoring heritage values of national cultural monuments or of property in a historic site (objects of national cultural monuments, historical buildings or listed monuments) and the production and sale covered by the Centre for folk art production.

The development of regional tourism, in which folk crafts are irreplaceable, can bring prosperity to the region. In this context, human resources in the regions represent a competitive advantage. Tourism is a service sector, where human capital is very important in terms of quality of service. In order young people in the regions have an incentive to perform business in these areas, the support from the state through various incentives and measures, particularly in regions with high unemployment is indispensable. Slovak regions have rich natural and cultural wealth, which creates a favourable and competitive environment in the context of spending leisure time not only for domestic but mainly foreign tourists and visitors. In the context of the creative industries in tourism there cannot be avoided the field of sports, lotteries, games as well as the field of science, research and education [8].

Article purpose. The main aim of this paper is to describe the possibilities of the regional development based on support of creative industry in the area of sustainable tourism. Our findings are based on interviews with experts in the given area and their experience in enterprising in this field. Analysis of interviews will be the main source for elaboration of our recommendations for support of creative industry and increase of employment in the regions suffering the high unemployment and diminishing regional disparities.

Presentation of the main research data. Based on the completed expert interviews with professionals in the field of tourism and specialists in traditional crafts we have gained knowledge about which steps would be suitable for the development of handicrafts and tourism in different regions and such knowledge can gain real contours and bring the desired results. Answering the question in which dimensions socio-economic development in the regions could be developed, the experts see great potential for development of regions in the development of accommodation and catering services, namely the development of tourism in which the folk crafts are irreplaceable. In this context, human resources in the regions represent a competitive advantage but experts point out that there is necessary:

$>$ increased support from the state as a coordinator in promoting sustainability;

$>$ support for projects in the context of regional development;

$>$ support and development of rural identity;

$>$ promoting employment in the services and crafts;

$>$ support of rural-regional tourism as a guarantee of sustainability.

The question about which forms of sustainable tourism should be most encouraged and developed in terms of positive impact on the region, the experts agree that each region has its own specifics that need to be supported and developed, in particular all forms of rural tourism that protect the environment while allowing the cultural, sporting, social and sightseeing activities for visitors in the visited region. In the context of sustainability whether the tourism industry is able to bring to the regions improvement of the quality of life for long-term unemployed and handicapped people, the experts clearly agree on this, assuming the creation of conditions, rules, legislation, tax policy, action plans for the least developed regions and other documents. Development of traditional folk crafts and tourism is bound to provide services and manufacture of products with a high proportion of manual labour, which places demands on the need for human resources. The major role there is played by family business, which should be more preferred, thus increasing the standard of living of the individual families and strengthening the development of the regions. The question of financing is a very pertracted area. Even experts have approached the issue this way and a response of many of them was that they see the great administrative barriers and financial burden in developing projects for the 
purpose of raising capital through funds. European funds should be a priority to fund infrastructure development of tourist centres, which is the basis for more significant improvement of services and thus higher visitor satisfaction. It is important to pool resources and integrate actors to work together. Financing of state advertising in comparison with major competitors of Slovakia is insufficient.

Conclusion and prospects for further research. In order creative industries through the folk arts, crafts and tourism in the Slovak regions can develop in a balanced way to harness their full potential and create high added value in the various sectors of society, it is necessary to invest in the development of public policies. An important role is played by supporting links between creativity and innovation. It is essential to promote the interconnection of policies and measures in the areas of creativity, innovation, transfer of knowledge and technologies; encourage the business environment to increase employment of creative professionals; promote linkages to sectors of cultural tourism, education, local and regional development and internationalization of policies and initiatives.

To achieve this, the support of local, territorial and regional authorities is necessary in order to create favourable conditions for the development of creative industries. We also need to look for tools to support specific activities and encourage young people to entrepreneurial activities or selfemployment.

\section{LIST OF SOURCES}

1. Ambrozy, M. 2016. Dialekt ako jeden z prameňov kultúry, In: Međunarodni naučni zbornik Pravo Ekonomija Menadžment I., Srpsko Razvojno Združenje, Bački Petrovac, 2016, ISBN 978-86-80394-06-0, pp. 20 - 27.

2. Danglová, O. 2007. Ludové umenie na Slovensku. Kontexty a súvislosti. In Tradícia dnes? Ústredie l'udovej umeleckej výroby, Bratislava. http://www.ludovakultura.sk/index.php?id=11

3. Florida, R. 2002. The Rise of the Creative Class and How it's Transforming Work, Leisure, Community and Everyday Life. New York : Basic Books, 2002. ISBN 978-1864032567.

4. Kamińska, A. 2016. Uwarunkowania aktywności innowacyjnej predsiebiorstw przemyslowych Conditions of the innovative activity of industrial enterprises DOI: 10.15611/noz.2016.1.06 In. NAUKI O ZARZACDZANIU MANAGEMENT SCIENCES 1(26) Wrocław: Wydawnictwo Uniwersytetu Ekonomicznego we Wrocławiu ISSN 20806000 e-ISSN 2449-9803.

5. Kloudová, J. a KOL. 2010. Kreativny ekonomika. Praha: Grada, 2010. ISBN 978-80-247-3608-2.

6. Verešová J., B. JURAKOVÁ, 2014. Ludové zvyky, tradície, remeslá vo výchove mimo vyučovania, MPC Bratislava, 74 s., ISBN: 978-80-8052-673-3.

7. Creative economy report (2010) online: http://unctad.org/en/Docs/ditctab20103_en.pdf

8. Stratégia rozvoja kreatívneho PRIEMYSLU v Slovenskej republike, Návrh: Ministerstvo kultúry Slovenskej republiky a Ministerstvo hospodárstva Slovenskej republiky Bratislava december 2014

9. Ministerstvo kultury slovenskej republiki online: http://www.culture.gov.sk/

Одержано 13.06.2017p. 